\title{
Perceived organizational support and organizational trust in primary schools ${ }^{1}$
}

\author{
Sultan Bilge Keskinkılıç Kara ${ }^{2}$ \\ Demet Zafer Güneş ${ }^{3}$ \\ Nazlı Nazar Aydoğan ${ }^{4}$
}

\begin{abstract}
The purpose of the present study is to determine the relationship between organizational support and organizational trust of teachers. Organizational support is recognizing the contribution of employees, appreciating and paying attention to them in the organizations. Organizational trust refers to an organizational climate that the employees behave each other in an honest, realistic, helpful and coherent way. The study sample involves 470 primary school teachers working in Tuzla during 2013-2014 educational year. In the present study, the data was collected through the perceived organizational support scale and trust scale. SPSS 21.00 programs were used in analysis of the data. The relationships was tested by Pearson Moments Product Correlation Coefficient. Regression Analysis was used for testing predictive power. Positive, low-level and significant correlations were found towards perceived organizational support and sub-dimensions with organizational trust. Regression analyzes revealed that organizational trust was positively predicted from educational support, administrative support and justice variables. Educational support predicts a high part of the variance. These three variables explain the $10 \%$ of the organizational trust.
\end{abstract}

Keywords: Organizational support; organizational trust; primary schools; teacher.

\section{Introduction}

Organizational support is individual's perception about being valued and being regarded of well behaviors by the other people in the organization (Eisenberger, Hutchison \& Sowa, 1986). The employee who is approved, respected, given all he need and retribution of his effort by organization, in which he is working, will display the best level performance in order to achieve the goals of the organization (Rhodas \& Eisenberger, 2002). Individual waits for being recognized, regarded and appreciated of his/her contributions, which are directed to the aim of the

\footnotetext{
${ }^{1}$ This article was presented at the ICBT Institute: International Academic Conference, Paris, 2015

2 Assist. Prof. Dr., Faculty of Education, İstanbul Sabahattin Zaim University, bilge.kara@izu.edu.tr

3 Assist. Prof. Dr., Faculty of Education, İstanbul Sabahattin Zaim University, demetzafer@gmail.com

${ }^{4}$ Research Assistant, Faculty of Education, Okan University, nazli.aydogan@,okan.edu.tr
} 
Keskinkilıç Kara, S. B., Zafer Güneş, D., \& Nazar Aydoğan, N. (2015). Perceived organizational support and organizational trust in primary schools. International Journal of Human Sciences, 12(2), 385-393. doi: $10.14687 /$ ijhs.v12i2.3326

organization. By the agency of organizational support the employee meets the need of recognition, honoring and being respected and be psychologically in a good mood.

The most important support resources of individuals are administrators and colleagues (Sabuncuoğlu, 2007; Yoon \& Lim, 1999). The appropriate behavior of administrator contributes to organizational support because according to employee, it means his existence is interested in this organization (Rhoades \& Eisenberger, 2002).

Because administrators are representatives of organization, employees integrate administrators' behaviors, which are towards them in the organization, with the organization and perceive them as attitudes. This situation affects employees' behaviors towards the organization directly (Rhoades \& Eisenberger, 2002). Organizational support that is perceived by individual occurs due to organization's voluntary actions to individuals rather than legal and directorial rights, which are reported to individual. These actions can be as rewards, improving work, advancement, agreeing with the decision, valuing the ideas.

Conducted researches suggested that there is a positive relation between organizational support and employee' commitment (Howes, Cropanzano, Grandey, \& Mohler; Islam, Khan, Ahmad, Ali, Ahmed \& Bowra, 2013; Kaplan \& Öğüt, 2012; Özdevecioğlu, 2003), motivation (Mitchell, Gagne, Beaudry \& Dyer, 2013), job performance (Arshadi \& Hayavi, 2013) and it also decreases the turnover intention. Also researches on teachers (Greenglass, Fiksenbaum and Burke, 1996; Littrell, Billingsley and Cross ,1994) suggested that organizational support positively effects the teachers' job satisfaction and decreases their stress and burnout level.

\section{Organizational Trust}

Human, which is one of the most important funds of organizations, has two way relations inside the organization. Employee's sense of trust underlies these relations. It is stated that trust is not only important in organization life; it is also an important element of social relations (KalemciTüzün, 2007). According to employees trust, which is perceived by employees in the organization, can be both a need and a factor that affects organizational behaviors of them in a positive or negative way.

Trust is a factor that holds people together psychologically, gives them a sense of security and should underlie human relations (Ünsal, 2004). Organizational trust states employees' trust towards administration and employees' believes in what administrator tells them and expectations that actions of administration (Şimşek \& Taşç1, 2004), will be beneficial to them rather than harmful (Erdem \& İşbaş1, 2000). Organizational trust can be considered as psychological environment that should be generated by participation of organization's all members. 
Keskinkilıç Kara, S. B., Zafer Güneş, D., \& Nazar Aydoğan, N. (2015). Perceived organizational support and organizational trust in primary schools. International Journal of Human Sciences, 12(2), 385-393. doi: $10.14687 /$ ijhs.v12i2.3326

In fact, an administration, which institutionalizes trust and distributes trust to every part of organization, will be in a more advantaged situation about achieving individual and organizational goals than the other organizations (Erdem, 2003). Therefore, it can be suggested that providing precondition of trust in the organization and creating trustful climate gains more importance in this rapidly changing world.

Organizational trust provides creation of positive organizational climate (Özan-Boydak \& Özdemir, 2013), organizational commitment (Çubukçu, 2010; Özgan,2011), enhancement of risk and responsibility, it also reduces conflict (Özgan, 2011), turnover intention (Yazıcıŏlu, 2009) and cynicism (Kılınç, 2010; Türköz, Polat \& Coşar, 2012). It can be claimed that organizational trust is an important factor while creating an organization, which is effective, productive, workable, and open to communication also in which employees respecting each other and giving importance to helping each other.

It can be stated that the perception of organizational support has an important role in order to provide organizational trust. Through their actions, which are direct to the goals, if employees feel their colleagues', administrators' and other partners' support, their trust towards the organization and their administrator can increase. When literature is examined, it is seen that a lot of different researches, related to organizational trust and organizational support, have been made in the area of business, health and tourism. However, the number of researches that have been made about organizational trust and organizational support in the education area is limited. It has been thought that this research can contribute to education administrators' implementations. Additionally, it is expected that the perception of organizational support, organizational trust level and the relation between them in education institutions will contribute to studies related to teachers' performance and effectiveness of their educational situation.

The aim of this research is to determine the relation between perceived organizational support by primary school teachers and organizational trust. The specified sub aims of this research are below:

1. What kind of a relation is between perceived organizational support by teachers and organizational trust?

2. At which level do perceived organizational support by teachers and its sub dimensions predict organizational trust? 
Keskinkilıç Kara, S. B., Zafer Güneş, D., \& Nazar Aydoğan, N. (2015). Perceived organizational support and organizational trust in primary schools. International Journal of Human Sciences, 12(2), 385-393. doi: $10.14687 /$ ijhs.v12i2.3326

\section{Method}

This is a descriptive research which has been made by using relational screening model. Descriptive research models are models that aim to identify existence of change and/or change level between two or much more variables (Karasar, 2009).

\section{Population and Sample}

700 teachers, who are working in 2013-2014 school term in Tuzla, İstanbul, are constituted the target population of this study. Sampling has not been made because target population of this study is reachable. 482 of the distributed scales have been returned but inside of them, 12 scales are invalid due to incorrect marking. Because of this, 470 scales are evaluated. 470 teachers represent $67 \%$ of the population. This sample rate is convenient with 0.5 error margin (Balc1,1999).

\section{Data Collection Tools}

Two scales have been used as data collection tools in this study. Perceived Organizational Support Scale (AÖDÖ- POSS), which is developed by Derinbay (2011), is used in order to identify the level of teachers' perception of organizational support. POSS is a 5 point Likert Scale, which is made up of 29 items and 3 dimensions. Cronbach Alpha coefficient is 0.95. Cronbach Alpha coefficients, which belong to POSS's sub dimensions, are 0.83 for educational support sub dimension, 0.89 for administrative support sub dimension and 0.92 for justice sub dimension. In this study, the Cronbach Alpha reliability coefficient was found to be 0.86 for educational support sub dimension, 0.84 for administrative support sub dimension and 0.89 for justice sub dimension.

Organizational Trust Scale (OTS), developed by Yilmaz (2006), is used in order to identify teachers' organizational trust levels. OTS is a 5 point Likert Scale, which is made up of 22 items and 3 dimensions. The whole scale's Cronbach Alpha is 0.92. Cronbach Alpha coefficients, which belong to OTS's sub dimensions, are 0.89 for trust to administrator, 0.87 for trust to colleague, 0.82 for trust to stakeholders. In this study, the Cronbach Alpha reliability coefficient was found to be 0.89 for trust to administrator, 0.90 for trust to colleague, 0.85 for trust to stakeholders.

\section{Analysis of the Data}

In the analysis of the data Pearson Moments Product Correlation Coefficient was used to identify the relationship among variables. Simple linear regression was used to predict the organizational trust (dependent variable) using sub dimensions of perceived organizational support (independent variable). 
Keskinkilıç Kara, S. B., Zafer Güneş, D., \& Nazar Aydoğan, N. (2015). Perceived organizational support and organizational trust in primary schools. International Journal of Human Sciences, 12(2), 385-393. doi: $10.14687 /$ ijhs.v12i2.3326

\section{Findings}

The results of the Pearson Correlation Analysis between dependent and independent variables are given in table 1.

Table 1: The Correlation Analysis Result about the Relation between Perceived Organizational Support by Teachers and Organizational Trust

\begin{tabular}{|c|c|c|c|c|c|c|c|c|}
\hline Variables & 1 & 2 & 3 & 4 & 5 & 6 & 7 & 8 \\
\hline $\begin{array}{l}\text { 1. Trust to } \\
\text { Administrator } \\
\text { 2. Trust to Colleagues }\end{array}$ & $.681^{* *}$ & 1 & & & & & & \\
\hline $\begin{array}{l}\text { 3. Trust to } \\
\text { Stakeholders }\end{array}$ & $.545^{* *}$ & $.630 * *$ & 1 & & & & & \\
\hline $\begin{array}{l}\text { 4. Organizational } \\
\text { Trust }\end{array}$ & $.872^{* *}$ & $.901 * *$ & $.815^{* *}$ & 1 & & & & \\
\hline $\begin{array}{l}\text { 5. Educational } \\
\text { Support }\end{array}$ & $.264 * *$ & $.278 * *$ & $.233^{* *}$ & $.300 * *$ & 1 & & & \\
\hline $\begin{array}{l}\text { 6.Administrative } \\
\text { Support }\end{array}$ & $.187^{* *}$ & $.204 * *$ & $.104^{*}$ & $.196^{* *}$ & $.587 * *$ & 1 & & \\
\hline 7.Justice & $.214^{* *}$ & $.255^{* *}$ & $.112^{*}$ & $.230^{*}$ & $.521 * *$ & $.892^{* *}$ & 1 & \\
\hline $\begin{array}{l}\text { 8. Organizational } \\
\text { Support }\end{array}$ & $.238^{*}$ & $.267 * *$ & $.149 * *$ & $.257 * *$ & $.713^{* *}$ & $.959 * *$ & $.952^{* *}$ & 1 \\
\hline
\end{tabular}

If correlation coefficient as absolute value is between $0.70-1.00$, it means high; if it is between $0.70-0.30$, it means medium; if it is between $0.30-0.00$, it means low level relation (Büyüköztürk, 2009). According to the result of correlation analysis in Table 1, a low-level significant positive relation is identified between perceived organizational support by teachers and sub dimensions of organizational trust, which are trust to administrators $(r=0.238 ; \mathrm{p}<0.01)$, trust to colleagues $(\mathrm{r}=0.267 ; \mathrm{p}<0.01)$ and trust to stakeholders $(\mathrm{r}=0.149 ; \mathrm{p}<0.05)$. A low-level significant positive relation is found between perceived educational support by teachers and sub dimensions of organizational trust, which are trust to administrators $(\mathrm{r}=0.264 ; \mathrm{p}<0.01)$, trust to colleagues $(\mathrm{r}=0.278 ; \mathrm{p}<0.01)$ and trust to stakeholders $(\mathrm{r}=0.233 ; \mathrm{p}<0.01)$. And also a low-level significant positive relation is found between perceived administrative support by teachers and sub dimensions of organizational trust, which are trust to administrators $(\mathrm{r}=0.187 ; \mathrm{p}<0.01)$, trust to colleagues $(\mathrm{r}=0.204 ; \mathrm{p}<0.01)$ and trust to stakeholders $(\mathrm{r}=0.104 ; \mathrm{p}<0.05)$.

The regression co-efficients were analyzed in order to determine whether independent variables' ability to predict dependent variables was statistically important in the model. In Table 2, 
Keskinkilıç Kara, S. B., Zafer Güneş, D., \& Nazar Aydoğan, N. (2015). Perceived organizational support and organizational trust in primary schools. International Journal of Human Sciences, 12(2), 385-393. doi: $10.14687 /$ ijhs.v12i2.3326

the results of the regression analysis for the variables that affected teachers' organizational trust levels are given.

Table 2: Regression Analysis Results Related to Prediction of Organizational Trust

\begin{tabular}{lccccc}
\hline \multicolumn{1}{c}{ Variable } & $\mathrm{B}$ & Standard Error & $\beta$ & $\mathrm{t}$ & $\mathrm{p}$ \\
\hline $\begin{array}{l}\text { Educational } \\
\text { Support } \\
\text { Administrative }\end{array}$ & 0.791 & 0.149 & 0.284 & 5.290 & .000 \\
$\begin{array}{l}\text { Support } \\
\text { Justice }\end{array}$ & 0.353 & 0.165 & 0.217 & -2.135 & .033 \\
\hline $\begin{array}{l}\mathrm{R}=0.32, \mathrm{R}^{2}=0.10 \\
\mathrm{p}<.05\end{array}$ & 0.370 & 0.129 & 0.275 & 2.861 & .004 \\
\hline
\end{tabular}

Educational support, administrative support and justice variables have effects on organizational trust is seen as a result of regression analysis, which has been done in order to reveal at which level educational support, administrative support and justice variables that are thought to have effect on organizational trust, predict organizational trust [Adjusted $\left.\mathrm{R}^{2}=0.10\right]$. Aforesaid these three variables, together explains \%10 of organizational trust. According to standardized regression coefficients, predictor variables' importance order is relatively educational support $(\beta=0.284)$, administrative support $(\beta=0.275)$ and justice $(\beta=0.217)$. On regarding significance tests' regression coefficients, it is seen that educational support variables and justice variables at a level of $\mathrm{p}<0.01$, administrative support variable at a level of $\mathrm{p}<0.05$, which are from predictor variables, are significant predictors on organizational trust.

\section{Result and Discussion}

According to study result, a low level positive significant relation is identified between perceived organizational support by primary school teachers, educational support and administrative support and sub dimensions of organizational trust, which are trust to administrators, trust to colleagues and trust to stakeholders. In researches, being a positive relation between perceived organizational support and organizational trust (Tan \& Tan, 2000; Ferres at all., 2005; Canipe, 2006; De Coninck, 2010; Polat, 2010; Taşdan \& Yalçın, 2010; Bobbio, Bellan \&Manganelli, 2012; Narang \& Singh, 2012; Duffy \& Lilly, 2013) and perceived social support by employees helps to create organizational trust is stated ( Eisenberger et all. 1990). These findings coincide with this study's findings. On the ground of this result, it can be said that the more teachers' support level from school increase, the more their trust level to school increase.

Educational support, administrative support and justice variables have effects on organizational trust is seen as a result of regression analysis, which has been done in order to reveal 
Keskinkilıç Kara, S. B., Zafer Güneş, D., \& Nazar Aydoğan, N. (2015). Perceived organizational support and organizational trust in primary schools. International Journal of Human Sciences, 12(2), 385-393. doi: $10.14687 /$ ijhs.v12i2.3326

at which level educational support, administrative support and justice variables, thought to have effect on organizational trust, predict organizational trust. Aforesaid these three variables together explains $\% 10$ of organizational trust and also it is seen that the best predictor of organizational trust is educational support. When organization supports their employees, this helps to constitute trust environment in organization. Result of this study shows that educational support is important to provide trust in schools. When teachers perceive educational support, administrative support and justice in their actions towards the goal, their trust to school can increase. Teachers, who are working in schools that do not constitute trust environment, can increase their effort towards selfdefenses and because of this, the aims of education and school can fail. Therefore effort should be made in order to constitute trust environment, which is necessary in schools. In this context, supporting teachers in school can be effective for also bringing into safety.

This study has been implemented to primary schools in Tuzla. In order to generalize results of the study, it is advised to be taken a greater sample, which consists of middle school, high school and higher education institutions. Organizational support concept can be investigated deeply by using qualitative research method. While correlating organizational trust concept with organizational support in the meantime it can be advised to be studied by correlated with job satisfaction, team work, organizational citizenship behavior, organizational justice and organizational commitment, which are thought to affect employee' organizational behaviors.

\section{References}

Arshadi, N. \& Hayavi, G. (2013). The effect of perceived organizational support on affective commitment and job performance: mediating role of OBSE. Social and Behavioral Sciences, 84, $739-743$.

Büyüköztürk, Ş. (2009). Sosyal bilimler için veri analiz̧i el kitabı. (10.Baskı) Ankara: Pegem A Akademi.

Canipe, J.S. (2006). Relationships among trust, organizational commitment, perceived organizational support, and turnover intentions. Yayımlanmamış Doktora Tezi, Alliant International University.

Çubukçu, K.(2010). Örgütsel güven kavrammmn ögretmenler açısından örgütsel bağhlhk üzerine etkileri. Yayımlanmamış Yüksek Lisans Tezi, Ankara: Gazi Üniversitesi Eğitim Bilimleri Enstitüsü.

Derinbay, D. (2011). İlkögrretim okullarnnda görev yapan ögretmenlerin algzladıklar örgütsel destek düreyleri. Pamukkale Üniversitesi Sosyal Bilimler Enstitüsü Yayınlanmamış Yüksek Lisans Tezi. Denizli.

Duffy, J.A. \& J. Lilly (2013), "Do Individual Needs Moderate the Relationships between Organizational Citizenship Behavior, Organizational Trust and Perceived Organizational Support?", Journal of Behavioral \& Applied Management, 14 (3), 185-197. 
Keskinkilıç Kara, S. B., Zafer Güneş, D., \& Nazar Aydoğan, N. (2015). Perceived organizational support and organizational trust in primary schools. International Journal of Human Sciences, 12(2), 385-393. doi: $10.14687 /$ ijhs.v12i2.3326

Eisenberger, R., Huntington, R., Hutchison, S. and Sowa, D. (1986). Perceived organizational support. Journal of Applied Psychology, 71(3), 500-507.

Erdem, F. \& İşbaşı, J.Ö. (2000). Takım Çalışmalarında güven ve güvensizlik: performans için koşulsuz güven mi, optimum güven mi?’, Erciyes Üniversitesi 8. Ulusal Yönetim ve Organizasyon Kongresi Bildiriler, 25-27 Mayıs 2000, Nevşehir.

Erdem, F. (2003). Örgütsel yaşamda güven. F. Erdem (ed.), Sosyal bilimlerde güven. Ankara: Vadi Yayınları.

Ferres N, Connell J, Travaglione A (2005). The effect of future redeployment on organizational trust. Strat Change, 14, 77-91.

Greenglass, E., Fiksenbaum, L., \& Burke, R. J. (1996). Components of social support, buffering effects and burnout: Implications for psychological functioning. Anxiety, Stress, and Coping, 9, 185-197.

Howes, J., C., Cropanzano, R., Grandey, A.,A., and Mohler, C. (200). Who is supporting whom? quality team effectiveness and perceived organizational support. Journal of Quality Management, 5, 207-223.

Islam, T., Khan, S., Ahmad, U.,N., Ali, G., Ahmed, I. and Bowra, Z., A. (2013). Turnover intentions: the influence of perceived organizational support and organizational commitment. Procedia - Social and Behavioral Science, 103, 1238 - 1242.

Kalemci-Tüzün, İ. (2007). Güven, örgütsel güven ve örgütsel güven modelleri. Karamanoğlu Mehmetbey Üniversitesi Sosyal ve Ekonomike Arastrmalar Dergisi, Aralı, 93-118

Kaplan, M. \& Öğüt, A. (2012). Alg1lanan örgütsel destek ile örgütsel bağlll1k arasındaki ilişkinin analizi: otel işletmelerinde bir uygulama. Süleyman Demirel Üniversitesi İktisadi ve İdari Bilimler Dergisi, 17(1), 387-401.

Kllinç, A. Ç. (2010). Okul yöneticilerinin etik liderlik davranışlarn gösterme düzeyleri ile öğretmenlerin yaşadıklarn örgütsel güven ve yuldirma arasindaki ilişki. Yayımlanmamış Yüksek Lisans Tezi, Ankara: Gazi Üniversitesi Eğitim Bilimleri Enstitüsü.

Littrell, P. C., Billingsley, B. C., \& Cross, L. H. (1994). The effects of principal support on special and general educators' stress, job satisfaction, school commitment, health, and intent to stay in teaching. Remedial and Special Education. 15, 297-310.

Mitchell, J., I., Gagne, M., Beaudry, A. and Dyer, L. (2012). The role of perceived organizational support, distributive justice and motivation in reactions to new information technology. Computers in Human Behaviour, 28, 729-738.

Narang, L. \& Singh, L. (2012). Role of perceived organizational support in the relationship between HR practices and organizational trust. Global Business Review, 13(2), 239-249.

Özan-Boydak, M. \& Özdemir, T.Y. (2013). İlköğretim kurumu öğretmenlerinin örgütsel güven düzeyleri: Nitel bir çalışma. Gaz̧iantep University Journal of Social Sciences, 12(3), 469-486.

Özdevecioğlu, M. (2003). Algılanan Örgütsel Destek ile Örgütsel Bağlllık Arasındaki ilişkilerin Belirlenmesine Yönelik Bir Araştırma. Dokuz Eylül Üniversitesi İktisadi ve İdari Bilimler Fakültesi Dergisi, 2 (18), 113-130.

Özgan, H. (2011). Örgütsel davranış bağlamında öğretmenlerin örgütsel adalet, güven, bağlllik, yönetici değerlendirme ve çatışma yönetimi stratejileri algıları arasındaki ilişkilerin incelenmesi. Kuram ve Uygulamada Ë̆itim Bilimleri, 11(1), 229-247. 
Keskinkilıç Kara, S. B., Zafer Güneş, D., \& Nazar Aydoğan, N. (2015). Perceived organizational support and organizational trust in primary schools. International Journal of Human Sciences, 12(2), 385-393. doi: $10.14687 /$ ijhs.v12i2.3326

Polat, S. (2007). Ortä̈gretim ögretmenlerinin örgütsel adalet algilar, örgütsel güven düreyleri ile örgütsel vatandaşlık davranıslar arasındaki ilişkei. Yayımlanmamış doktora tezi, Kocaeli Üniversitesi, Sosyal Bilimler Enstitüsü, Kocaeli.

Polat, S. (2010). The effect of organizational support; perception of teachers on organizational trust perception of their schools. African Journal of Business Management, 4 (14), 3134-3138.

Rhoades, L. \&Eisenberger, R. (2002). Perceived organizational support: a review of the literature. Journal of Applied Psychology, 87(4), 698-714 DOI: 10.1037//0021-9010.87.4.698.

Sabuncuoğlu, E.T. (2007). Eŭitim, örgütsel bağlılık ve işten ayrılma niyeti arasındaki ilişkilerin incelenmesi, Ege Akademik Bakus Dergisi, 7 (2), 613-628.

Solomon, R., C. ve Flores, F. (2001). İs dünyasında, politikada, ilişkilerde ve yaşamda güven yaratmak. İstanbul: MESS Yayınları.

Şimşek, S. \& Taşçı A. (2004). Örgütlerde güven konsepti ve emniyet örgütünde güven modellerinin değerlendirilmesi. Polis Dergisi, 34, 1-8.

Tan, H. H. \& Tan, C. S. (2000). Toward the differentiation of trust in supervisor and trust in organization. Genetic, Social, and Psychology Monographs, 126, 241-260.

Taşdan, M. \& Yalçın, E. (2010). ilköğretim okulu öğretmenlerinin algıladıkları sosyal destek ile örgütsel güven düzeyleri arasındaki ilişki düzeyi. Kuram ve Uygulamada Eğitim Bilimleri, 10(4), 2569-2620.

Türköz, T., Polat, M. \& Coşar, S. (2012). Çalışanların örgütsel güven ve sinizm algılarının örgütsel bağlllıkları üzerindeki rolü. Yönetim ve Ekonomi, 20 (2), 285-302.

Ünsal, P. (2004). Örgütlerde güven alg1sı. Kişisel Gelişimde Çağdaş Yönelimler Sempozyumu Bildiriler Kitabı, Ankara: Ankara Eğitim ve Doktrin Komutanlığ1.

Yazıcıŏ̆lu, İ., (2009). Konaklama işletmelerinde işgörenlerin örgütsel güven duyguları ile iş tatmini ve işten ayrılma niyetleri üzerine bir alan araştırması. Elektronik Sosyal Bilimler Dergisi, 8 (30), 235-249.

Y1lmaz, K. (2006). Güven ölçeği’nin geçerlik ve güvenirlik çalışması. Sakarya Üniversitesi Ë̆itim Fakültesi Dergisi, 11, 69-80.

Yoon, J. \& Lim, J.,C. (1999). Organizational support in the workplace: the case of Korean hospital employees, Human Relations, 52 (7), 923-945. 